\title{
Survival, lifetime production, and profitability of Normande $\times$ Holstein, Montbéliarde $\times$ Holstein, and Scandinavian Red $\times$ Holstein crossbreds versus pure Holsteins
}

\author{
B. J. Heins,${ }^{* 1}$ L. B. Hansen, ${ }^{*}$ and A. De Vriest \\ *Department of Animal Science, University of Minnesota, St. Paul 55108 \\ †Department of Animal Sciences, University of Florida, Gainesville 32611
}

\begin{abstract}
Pure Holstein $(\mathrm{HO})$ cows $(\mathrm{n}=416)$ were compared with Normande $(\mathrm{NO}) \times \mathrm{HO}(\mathrm{n}=251)$, Montbéliarde $(\mathrm{MO}) \times \mathrm{HO}(\mathrm{n}=503)$, and Scandinavian Red $(\mathrm{SR})$ $\times$ HO $(\mathrm{n}=321)$ crossbred cows for survival, lifetime production, and profitability in 6 commercial herds in California. The SR crossbred cows were sired by both Swedish Red and Norwegian Red bulls. Cows calved from June 2002 to January 2009. For analysis of survival to subsequent calvings, lifetime production, and profitability, data were restricted to 3 of 6 herds because they had at least 20 cows in each of the breed groups. All cows had the opportunity to calve at least 4 times. Best prediction, which is used by USDA for national genetic evaluations in the United States, was used to determine lifetime production to $4 \mathrm{yr}(1,461 \mathrm{~d})$ in the herd after first calving from test-day observations. Production and survival were estimated after 4 yr to calculate lifetime profit. A profit function was defined to include revenues and expenses for milk, fat, protein, and other solids production; somatic cell count; reproduction; feed intake; calf value; salvage value; dead cow disposal; and fixed cost. The $\mathrm{NO} \times \mathrm{HO}(1.2 \%), \mathrm{MO} \times \mathrm{HO}(2.0 \%)$, and $\mathrm{SR}$ $\times$ HO cows $(1.6 \%)$ had significantly fewer deaths than did pure $\mathrm{HO}$ cows (5.3\%) during the first $305 \mathrm{~d}$ of first lactation. All crossbred groups had significantly more cows that calved a second, third, and fourth time, and had mean survival that was 300 to $400 \mathrm{~d}$ longer than did pure $\mathrm{HO}$ cows. The $\mathrm{NO} \times \mathrm{HO}, \mathrm{MO} \times \mathrm{HO}$, and $\mathrm{SR}$ $\times \mathrm{HO}$ cows had significantly higher lifetime fat plus protein production than did pure HO cows up to 1,461 $\mathrm{d}$ after first calving. For profitability (ignoring possible differences in health costs), $\mathrm{NO} \times \mathrm{HO}$ cows had $26 \%$ greater projected lifetime profit per cow, but $6.7 \%$ less profit per cow-day, than did pure $\mathrm{HO}$ cows. On the other hand, $\mathrm{MO} \times \mathrm{HO}$ and $\mathrm{SR} \times \mathrm{HO}$ cows had 50
\end{abstract}

Received May 10, 2011.

Accepted October 21, 2011.

${ }^{1}$ Corresponding author: hein0106@umn.edu to $44 \%$, respectively, more projected lifetime profit per cow and 5.3 to $3.6 \%$, respectively, more projected profit per cow-day than did pure HO cows.

Key words: crossbreeding, heterosis, survival, economics

\section{INTRODUCTION}

The Holstein (HO) breed has dominated global milk production for the past $25 \mathrm{yr}$, and the success of selection for milk production has contributed to the domination of the $\mathrm{HO}$ breed. However, dairy producers with $\mathrm{HO}$ cattle have observed a substantial decrease in survival of cows (Hare et al., 2006), increased death rate of cows (Miller et al., 2008), and a sharp decrease in cow fertility (Norman et al., 2009) in recent years. From an economic standpoint, high culling rates in pure $\mathrm{HO}$ cows are of great concern to dairy producers (Weigel et al., 2003); therefore, dairy producers around the world have turned to mating pure $\mathrm{HO}$ heifers and cows to AI bulls from breeds of dairy cattle other than $\mathrm{HO}$ to reduce these problems.

Touchberry (1992) reported survival of crossbred cows versus pure Guernsey and pure HO cows over a 20-yr period from 1949 to 1969, and 88\% of $\mathrm{HO}$ and Guernsey crossbred heifers survived to first calving, whereas only $83 \%$ of pure $\mathrm{HO}$ heifers survived to first calving. Eighty-five percent of crossbred cows calved twice; however, only $77 \%$ of pure HO cows calved twice (Touchberry, 1992). Furthermore, Touchberry (1992) combined measures of survival, growth, production, and reproduction into an economic index to calculate the total income per cow for crossbreds and purebreds. Crossbreds had $11.4 \%$ greater income per lactation at $\$ 1,497$ for crossbreds and $\$ 1,344$ for purebreds.

At Agriculture Canada, Vesely et al. (1986) reported no difference between crossbred cows of Ayrshire $x$ $\mathrm{HO}$ and pure $\mathrm{HO}$ cows for percentage leaving the herd from first to second lactation. However, from the same experiment, Hocking et al. (1988) used survival analysis and found crossbred cows of Ayrshire and HO had 
greater herd life than did pure HO cows. McAllister et al. (1994) used lifetime data for all animals until culling, death, or the end of the study, and lifetime survival and health, growth, reproduction, production, and salvage value were recorded. The result was that Ayrshire $\times$ HO cows had significantly greater annualized and discounted net return than did pure HO cows. From the same experiment, but with an alternative economic analysis using data from the first 3 lactations of cows, Gunjal et al. (1997) found that pure HO cows had the highest net present value, pure Ayrshire cows had the lowest net present value, and the crossbred cows were intermediate. The net present value indicated that pure HO cows were the most profitable compared with pure Ayrshire cows and crossbred cows.

McDowell and McDaniel (1968) reported that Ayrshire $\times \mathrm{HO}$ and Brown Swiss $\times$ HO cows did not differ significantly from pure $\mathrm{HO}$ cows for milk revenue or income over feed cost during first lactation; however, the inclusion of health treatments and mortality in their study resulted in crossbred cows being more profitable than pure HO cows.

The Animal Improvement Program Laboratory of the USDA (VanRaden and Sanders, 2003) reported that the mean productive life for crossbred cows was 24.3 mo compared with 23.8 mo for pure HO cows. Furthermore, VanRaden and Sanders (2003) compared the Net Merit, Cheese Merit, and Fluid Merit economic indexes for crossbreds and purebreds. Brown Swiss $\times$ HO and Jersey $\times$ HO cows were more profitable than pure HO cows for Net Merit and Cheese Merit, although no crossbred group was superior to pure HO cows for Fluid Merit (VanRaden and Sanders, 2003).

In Denmark, Sørensen et al. (2008) reported substantial heterosis $(+18 \%)$ for the productive life of crossbred cows compared with purebred cows. Furthermore, heterosis for traits of economic value for 3-breed rotational crossbreeding was greater than $21 \%$, and the study concluded that crossbreeding may provide a substantial amount of heterosis for total economic merit.

During the past decade, the Normande (NO), Montbéliarde (MO), and Scandinavian Red (SR) breeds were introduced into the United States and many other countries in the world for crossbreeding. Each of the 3 breeds has more than 300,000 cows on milk recording in its home country and has a sophisticated progenytesting program. No previous research has compared $\mathrm{NO} \times \mathrm{HO}, \mathrm{MO} \times \mathrm{HO}$, and $\mathrm{SR} \times \mathrm{HO}$ cows to pure $\mathrm{HO}$ cows for high-input dairying. Therefore, the objectives of this study were to compare $\mathrm{NO} \times \mathrm{HO}, \mathrm{MO} \times \mathrm{HO}$, and $\mathrm{SR} \times \mathrm{HO}$ cows with pure $\mathrm{HO}$ cows for 1 ) deaths and removals to first milk recording and to $305 \mathrm{~d}$ postpartum during first lactation, 2) survival to subsequent calving (up to fourth calving), 3) lifetime production, and 4) profitability. A companion paper (Heins and Hansen, 2012) reported results for the same herds of cows for fertility, SCS, and 305-d projected production.

\section{MATERIALS AND METHODS}

\section{Data}

A detailed description of the study and number of daughters per sire is reported in Heins and Hansen (2012). In brief, all cows initiated their first lactations between June 2002 and January 2005. Also, data collection spanned the period of time from June 2002 to January 2009. Calving dates, number of calves, and sex of calves born alive, breeding dates, pregnancy diagnoses of cows, DHI production, and disposal dates, along with reasons for disposal were provided by 6 commercial herds in California.

Data for this study were originally edited on test-day records (Heins et al., 2006b). However, many cattle did not survive to first milk recording; therefore, they were excluded from previously published results (Heins et al., 2006a). Data from herd records allowed the addition of 64 cows $(9 \mathrm{NO} \times \mathrm{HO}, 12 \mathrm{MO} \times \mathrm{HO}, 7 \mathrm{SR} \times$ $\mathrm{HO}$, and 36 pure $\mathrm{HO}$ ) that calved in these 6 herds in the same window of time as the previously reported cows, but died or were culled before first milk recording. Therefore, $251 \mathrm{NO} \times \mathrm{HO}, 503 \mathrm{MO} \times \mathrm{HO}, 321 \mathrm{SR}$ $\times \mathrm{HO}$, and 416 pure $\mathrm{HO}$ cows that calved for the first time from June 2002 to January 2005 were compared. The distribution of cows by herd and breed group is in Table 1, and the 6 herds were variable in number of cows and in extent of use of breeds for crossbreeding.

However, for the analysis of survival to subsequent calving, lifetime production, and profitability, the data were restricted to 3 of the 6 herds because they had at least 20 cows in each of the breed groups to provide a meaningful comparison of cows for lifetime performance within herds. Those 3 herds were herds 2,4 , and 6 in Table 1 with $168 \mathrm{NO} \times \mathrm{HO}, 369 \mathrm{MO} \times \mathrm{HO}, 218 \mathrm{SR} \times$ $\mathrm{HO}$, and 165 pure $\mathrm{HO}$ cows to analyze survival, lifetime production, and profitability. The data for this study included only crossbreds with $\mathrm{HO}$ dams and pure $\mathrm{HO}$ cows, and therefore, the mating system did not permit the separation of additive genetic and heterotic effects.

\section{Deaths and Survival}

Crossbreds and pure HO cows were compared for survival to the first test day for milk recording and to $305 \mathrm{~d}$ postpartum during first lactation. Cows that died or were removed before the first test day and up to $305 \mathrm{~d}$ postpartum were recorded in a binary manner as died or removed (1) or alive in the herd (0). Further- 
Table 1. Distribution of Normande $\times$ Holstein, Montbéliarde $\times$ Holstein, and Scandinavian Red $\times$ Holstein crossbred cows and pure Holstein cows by herd and breed group

\begin{tabular}{lcccc}
\hline Herd & $\begin{array}{c}\text { Pure } \\
\text { Holstein }\end{array}$ & $\begin{array}{c}\text { Normande } \\
\times \text { Holstein }\end{array}$ & $\begin{array}{c}\text { Montbéliarde } \\
\times \text { Holstein }\end{array}$ & $\begin{array}{c}\text { Scandinavian Red } \\
\times \text { Holstein }\end{array}$ \\
\hline 1 & 232 & 13 & 7 & 59 \\
2 & 51 & 60 & 94 & 84 \\
3 & 3 & 27 & 42 & 25 \\
4 & 74 & 45 & 85 & 19 \\
5 & 16 & 33 & 93 & 53 \\
6 & 40 & 251 & 503 & 321 \\
Total & 416 & & & \\
\hline
\end{tabular}

more, crossbreds and pure $\mathrm{HO}$ cows were compared for percentage of cows calving a second, third, and fourth time, because all cows had the opportunity to calve at least 4 times. Data were recorded in a binary manner as calved (1) or did not calve (0) a second, third, or fourth time. A $\chi^{2}$ test (SAS Institute, 2008) was used to compare each crossbred group to the pure HO cows for all measures of survival. Additionally, logistic regression (SAS Institute, 2008), with fixed effects of herd and breed group, was used to determine odds ratios and significance of contrasts between breed groups.

\section{Lifetime Production}

Edits were applied to test-day observations for lifetime production and were described in Heins and Hansen (2012). Best prediction provided daily production, adjusted for age at calving, from 1 to 999 DIM for any lactation of a cow with a maximum of 50 test days (Cole et al., 2009); therefore, best prediction was used to predict production each day of lactation, excluding the dry period, and daily production was summed across lactations to determine lifetime production. Every cow had the opportunity to survive at least $4 \mathrm{yr}$ $(1,461 \mathrm{~d})$ after first calving in these herds; therefore, lifetime was defined as the time from the date of first calving to $4 \mathrm{yr}(1,461 \mathrm{~d})$ in the herd after first calving. For lifetime production to 1,461 d, cows with records shorter than $305 \mathrm{~d}$ were not projected to $305 \mathrm{~d}$, and all production beyond $305 \mathrm{~d}$ in lactation was included. For statistical analysis of lifetime production (milk, fat, protein, and fat plus protein), the independent variables were fixed effects of herd and breed group. The general linear model procedure of SAS (SAS Institute, 2008) was used to obtain solutions and conduct the ANOVA. Cows that did not survive to the first test day for milk recording were not included in the analysis of lifetime production.

\section{Profitability}

Lifetime profit was estimated as a function of the revenue and expense of cows during the first 4 yr $(1,461 \mathrm{~d})$ after first calving, because all cows had the opportunity to survive to at least 4 yr after first calving. Profit per cow-day was then calculated as lifetime profit divided by total days in the herd for each cow. However, 352 cows $(66 \mathrm{NO} \times \mathrm{HO}, 160 \mathrm{MO} \times \mathrm{HO}, 90 \mathrm{SR} \times \mathrm{HO}$, and 36 pure HO cows) of the total of 920 cows in the 3 herds survived beyond $4 \mathrm{yr}$ after first calving.

The additional profit of the 352 cows that survived beyond the first 4 yr $(1,461 \mathrm{~d})$ after first calving was projected by multiplying the profit per day of a cow up to $4 \mathrm{yr}$ after first calving (excluding replacement cost, salvage value, or dead cow disposal cost) by the predicted number of additional days that a cow remained in the herd. Hazards (risk of leaving the herd each day) were obtained from the survival rates of cows using the actuarial method in the LIFETEST procedures of SAS (SAS Institute, 2008), which predicted the additional number of days a cow would survive in the herd beyond the first 4 yr after first calving. The additional projected profit was then added to the actual profit from the first $4 \mathrm{yr}$ after first calving to obtain the projected lifetime profit of a cow. In turn, projected profit per cow-day was obtained by dividing projected lifetime profit by projected total days in the herd since first calving for each cow.

Table 2 has default revenues and expenses used to determine lifetime profit. Milk price was $\$ 0.3441 / \mathrm{kg}$ of milk (\$0.023/kg for milk volume, $\$ 3.155 / \mathrm{kg}$ for fat solids, $\$ 7.064 / \mathrm{kg}$ for protein solids, and $\$ 0.395 / \mathrm{kg}$ for other solids), which was the mean milk price from 2007 to 2009 from component prices of the Federal Milk Marketing Order in the United States (USDA-AMS, 2010). Premiums for SCC (\$0.0008 per 1,000 somatic cells, plus or minus, from 350,000$)$ were likewise from Federal Milk Marketing Order prices in the United States from 2007 to 2009. The mean percentage of other solids in milk $(5.65 \%)$ was from Bailey et al. (2005).

The values of calves ( $\$ 250$ for heifers and $\$ 100$ for bulls) and salvage value (\$525) for culled cows were from the Lifetime Net Merit of the USDA-Animal Improvement Programs Laboratory (VanRaden, 2006). Calf value and salvage value were each assumed to be 
Table 2. Default revenues and expenses and alternative values for sensitivity analysis

\begin{tabular}{llcl}
\hline Variable & Unit & Value & Reference \\
\hline Revenue & & & \\
Milk price & $\mathrm{kg}$ & $\$ 0.3441$ & USDA-AMS $(2010)$ \\
Live female calf & Calf & $\$ 250$ & VanRaden $(2006)$ \\
Live male calf & Calf & $\$ 100$ & VanRaden $(2006)$ \\
Salvage value & Cow & $\$ 525$ & VanRaden (2006) \\
Expense & & & \\
Dead cow disposal & Cow & $\$ 125$ & Herds that were studied \\
Feed cost & $\mathrm{kg}(\mathrm{DMI})$ & $\$ 0.2306$ & California Department of Food and Agriculture (2009) \\
Replacement cost & Heifer & $\$ 1,200$ & Meadows et al. (2005) \\
Breeding cost & Breeding & $\$ 40$ & VanRaden (2006) \\
Fixed lactation cost & $\mathrm{d}$ & $\$ 1.50$ & Herds that were studied \\
Fixed dry cow cost & $\mathrm{d}$ & $\$ 2.00$ & California Department of Food and Agriculture (2009) \\
Sensitivity & $\mathrm{kg}(\mathrm{DMI})$ & $\$ 0.3171$ & California Department of Food and Agriculture (2009) \\
Higher feed cost & $\mathrm{kg}$ & $\$ 0.4544$ & USDA-AMS (2010) \\
Higher milk price & $\mathrm{kg}$ & $\$ 0.2339$ & USDA-AMS (2010) \\
Lower milk price & Heifer & $\$ 1,625$ & Cole and VanRaden (2009) \\
Greater replacement cost & Cow & $\$ 800$ & Herds that were studied \\
Higher salvage value & $\mathrm{kg}$ & $+35 \mathrm{~kg}$ for first and $+40 \mathrm{~kg}$ & Hazel et al. (2009) \\
Heavier BW for Normande $\times$ Holstein & for later lactations & \\
and Montbéliarde $\times$ Holstein & & & \\
\hline
\end{tabular}

the same for crossbred and pure HO cows. Dead cow disposal cost was $\$ 125$, which was the approximate cost for the herds in the study. For the 352 cows that survived beyond 4 yr after first calving, salvage value was reduced by weighted mean death rates of cows $(4.3 \%$ for $\mathrm{NO} \times \mathrm{HO}, 5.8 \%$ for $\mathrm{MO} \times \mathrm{HO}, 5.6 \%$ for $\mathrm{SR} \times \mathrm{HO}$, and $7.3 \%$ for pure HO cows) during third, fourth, and fifth lactation.

Daily DMI was predicted using NRC (2001) requirements based on daily FCM from best prediction (Cole et al., 2009), BW, and days postpartum for each cow. Daily DMI was summed across lactations of cows for the first 4 yr after first calving. Fixed BW of $545 \mathrm{~kg}$ for first lactation and $680 \mathrm{~kg}$ for second-and-later lactations was assumed for all crossbred and pure HO cows for the prediction of DMI, because actual BW were not available. The mean daily feed cost $(\$ 5.33 / \mathrm{d})$ for lactating cows in crossbred herds in California from 2007 to 2009 (California Department of Food and Agriculture, 2009) was divided by the total DMI weighted by one-third for first-lactation cows and two-thirds for later-lactation cows to obtain the feed cost of $\$ 0.2306$ per kilogram of DMI.

The replacement cost was $\$ 1,200$ per cow, which was assumed to be the mean cost to raise a replacement heifer in the United States (Meadows et al., 2005). Fixed breeding expense was assumed to be $\$ 40$ per breeding, which included heat detection, hormones for synchronization programs, labor, semen cost, and pregnancy examination (VanRaden, 2006). Additionally, a daily fixed cost of $\$ 1.50$ was assumed for each lactating cow, which included costs of milking parlor supplies and labor. Furthermore, a daily fixed cost of $\$ 2$ was assumed for cows during the dry period (California Department of Food and Agriculture, 2009).

Cows that did not survive to the first test day in a lactation were assigned $11.34 \mathrm{~kg}(25 \mathrm{lb})$ of $3.5 \% \mathrm{FCM}$ per day, which is considerably lower than the mean FCM for the first test day $(29.9 \mathrm{~kg} / \mathrm{d})$ for these herds. However, cows that died or were culled before the first test day were expected to have greater health problems that would reduce FCM. Additionally, cows that did not survive to the first test day were assigned zero premium for SCC, and $11 \mathrm{~kg}$ of DMI per day, which was the mean DMI of HO cows from NRC (2001) during the first week of lactation. All other revenues and expenses for cows that did not survive to the first test day were the same as cows that did survive to the first test day.

Profitability was calculated as projected lifetime profit per cow and projected profit per cow-day. Lifetime profit is an appropriate measure when the number of heifers calving is the limiting factor. This measure assumes no opportunity costs of delayed replacement. To account for the time value of money, revenues and costs were discounted from the day of first calving by the discount factor $1 /(1+0.05 / 365)^{t / 365}$, where $\mathrm{t}$ is the number of days since first calving, and the annual interest rate is 5\% (Brealey et al., 2009).

Profit per cow-day is an appropriate measure when the number of slots, or stalls, in the dairy is the limiting factor. We assumed cows that leave the herd are replaced by springing heifers of the same breed or crossbred group, and the supply of springing heifers was unlimited. We further assumed that the breed group demographics were constant over time. Consequentially, breed group total revenues and costs were constant 
over time as well. Daily costs were multiplied by $5 \%$ for the opportunity cost of capital tied up maintaining the herd.

\section{Sensitivity Analysis}

Sensitivity analyses were performed to evaluate the effects of changes in the input variables on projected lifetime profit per cow and projected profit per cowday. Alternative feed cost, milk price, replacement heifer cost, salvage value, as well as $\mathrm{BW}$ for $\mathrm{NO} \times \mathrm{HO}$ and $\mathrm{MO} \times \mathrm{HO}$ cows were used for sensitivity analysis (Table 2). Feed cost was increased from $\$ 0.2306 / \mathrm{kg}$ to $\$ 0.3171 / \mathrm{kg}$ of DMI. Two alternative milk price scenarios were higher milk price (32\% higher at $\$ 0.4544$ / $\mathrm{kg}$ ) and lower milk price (32\% lower at $\$ 0.2339 / \mathrm{kg})$, which coincided with component prices of $\$ 0.045 / \mathrm{kg}$ for milk volume, $\$ 3.527 / \mathrm{kg}$ for fat solids, $\$ 10.375 / \mathrm{kg}$ for protein solids, and $\$ 0.582 / \mathrm{kg}$ for other solids at the higher milk price, and with $\$ 0.019 / \mathrm{kg}$ for milk volume, $\$ 2.363 / \mathrm{kg}$ for fat solids, $\$ 4.352 / \mathrm{kg}$ for protein solids, and $\$ 0.130 / \mathrm{kg}$ for other solids at the lower milk price. Replacement heifer cost was increased from $\$ 1,200$ to $\$ 1,625$, which reflected circumstances when replacement heifers are sold for income rather than brought into the lactating herd or a higher cost of raising heifers. Salvage value was increased from $\$ 525$ to $\$ 800$. The $\mathrm{BW}$ for calculation of daily DMI from NRC prediction equations (NRC, 2001) for the $\mathrm{NO} \times \mathrm{HO}$ and $\mathrm{MO} \times$ $\mathrm{HO}$ cows were increased by $35 \mathrm{~kg}$ for first lactation and $45 \mathrm{~kg}$ for later lactations, respectively. Increased BW for the 2 crossbred groups was based on the results of Hazel et al. (2009), who reported $\mathrm{MO} \times \mathrm{HO}$ cows had $36 \mathrm{~kg}$ greater $\mathrm{BW}$ than did pure $\mathrm{HO}$ cows during first lactation that was all due to greater body condition and not because of greater frame size compared with pure HO cows.

For statistical analysis of projected lifetime profit per cow and projected profit per cow-day, independent variables were fixed effects of herd and breed group.
For lifetime profit per cow, the GLM procedure of SAS (SAS Institute, 2008) was used to obtain solutions and conduct the ANOVA. However, for profit per cow-day, the MIXED procedure of SAS (SAS Institute, 2008) was used to obtain solutions and conduct the ANOVA, because all cows had a profit or loss for each day of herd life. Additionally, for the analysis of profit per day, the WEIGHT statement of MIXED was used for the unbalanced number of days cows spent in the herd.

\section{RESULTS AND DISCUSSION}

\section{Survival}

The number and percentage of 1,075 crossbred and 416 pure HO cows that died or were removed during first lactation are in Table 3. Deaths and all losses reflected the actual cows that left the 6 herds before the first test day and up to d 305 of lactation. The difference of $\mathrm{NO} \times \mathrm{HO}, \mathrm{MO} \times \mathrm{HO}$, and $\mathrm{SR} \times \mathrm{HO}$ cows compared with pure HO cows was statistically significant $(P<0.05)$ in all cases.

Only 18 of 1,075 crossbred cows $(1.7 \%)$ compared with 22 of 416 pure HO cows $(5.3 \%)$ died during the first $305 \mathrm{~d}$ of the first lactation. More crossbred cows remained in the herds than did pure $\mathrm{HO}$ cows, with only $2.6 \%$ of crossbred cows removed (died or culled) before the first test day compared with $8.7 \%$ of pure HO cows. In other words, crossbred cows were onethird as likely to die or be culled compared with pure $\mathrm{HO}$ cows in these herds before the first test day. Also, $7.4 \%$ of the crossbred cows versus $15.9 \%$ of the pure HO cows in these 6 herds were removed by d 305 of the first lactation.

The death rates in this study are higher than those of Miller et al. (2008), who reported death rates during first lactation of $2.1 \%$ for pure HO cows; however, some deaths before the first test day were not included in their 2.1\%. Additionally, Miller et al. (2008) reported that death occurs more frequently in early lactation,

Table 3. Deaths and all losses during first lactation for Normande $\times$ Holstein, Montbéliarde $\times$ Holstein, and Scandinavian Red $\times$ Holstein crossbred cows and pure Holstein cows

\begin{tabular}{|c|c|c|c|c|c|c|c|c|}
\hline \multirow[b]{2}{*}{ Item } & \multicolumn{2}{|c|}{$\begin{array}{l}\text { Pure Holstein } \\
\quad(\mathrm{n}=416)\end{array}$} & \multicolumn{2}{|c|}{$\begin{array}{c}\text { Normande } \times \text { Holstein } \\
(\mathrm{n}=251)\end{array}$} & \multicolumn{2}{|c|}{$\begin{array}{l}\text { Montbéliarde } \times \text { Holstein } \\
(\mathrm{n}=503)\end{array}$} & \multicolumn{2}{|c|}{$\begin{array}{c}\text { Scandinavian Red } \times \\
\text { Holstein }(\mathrm{n}=321)\end{array}$} \\
\hline & $\mathrm{n}$ & $\%$ & $\mathrm{n}$ & $\%$ & $\mathrm{n}$ & $\%$ & $\mathrm{n}$ & $\%$ \\
\hline Prior to first test day & 15 & 3.6 & 2 & $0.8^{*}$ & 5 & $1.0^{* *}$ & 3 & $0.9^{*}$ \\
\hline $\begin{array}{l}\text { Calving to } 305 \mathrm{~d} \\
\text { All losses }\end{array}$ & 22 & 5.3 & 3 & $1.2^{* *}$ & 10 & $2.0^{* *}$ & 5 & $1.6^{* *}$ \\
\hline
\end{tabular}

${ }^{*} P<0.05$ for difference from pure Holsteins; ${ }^{* *} P<0.01$ for difference from pure Holsteins. 
which was the case for the pure HO in this study. Likewise, Dechow and Goodling (2008) found a 4.8\% culling rate before first milk recording for pure $\mathrm{HO}$ cows, which is lower than the $8.7 \%$ in this study, but they concluded that only $19 \%$ of herds record culls before first milk recording during first lactation. Death rates of cows during first lactation are likely higher in the United States than is often reported, because some cows that die before the first test day are excluded from data files.

Table 4 has survival to subsequent calving and odds ratios for crossbred and pure $\mathrm{HO}$ cows in the 3 herds that had at least 20 cows in each of the 4 breed groups, and all crossbred groups had a greater $(P<0.01)$ percentage of cows calve a second, third, and fourth time than pure HO cows. The main difference for survival of crossbred cows versus pure HO cows was up to the third calving. Only 11 to $15 \%$ of crossbred cows did not calve a second time, whereas $25 \%$ of pure $\mathrm{HO}$ cows failed to calve a second time. Seventy-one to $75 \%$ of crossbred cows calved a third time, whereas only $51 \%$ of pure $\mathrm{HO}$ cows calved a third time. Also, a greater percentage of crossbred cows (21 to 25\%) than pure HO cows calved a fourth time. The logistic regression analysis indicated higher odds ratios for survival to subsequent calving for crossbred cows compared with pure HO cows.

Survival rates to second, third, and fourth calving for pure HO cows in this study were comparable to those of Hare et al. (2006), who reported survival to second, third, and fourth calving of 73,50 , and $32 \%$, respectively. Factors contributing to disappointing survival rates of pure $\mathrm{HO}$ cows include increases in inbreeding, calving difficulty, increases in death rate, hampered fertility, and more health disorders (Pinedo et al., 2010).

\section{Lifetime Production}

Results for lifetime production during the first $4 \mathrm{yr}$ $(1,461 \mathrm{~d})$ after first calving are in Table 5 . The NO $\times$ HO cows were not significantly $(P>0.05)$ different from pure $\mathrm{HO}$ cows for lifetime milk volume; however,
$\mathrm{MO} \times \mathrm{HO}$ and $\mathrm{SR} \times \mathrm{HO}$ cows had significantly $(P<$ $0.05)$ higher lifetime milk volume than did pure $\mathrm{HO}$ cows. The $\mathrm{NO} \times \mathrm{HO}(P<0.05), \mathrm{MO} \times \mathrm{HO}(P<$ $0.01)$, and $\mathrm{SR} \times \mathrm{HO}$ cows $(P<0.01)$ had significantly greater lifetime fat, lifetime protein, and lifetime fat plus protein production than did pure $\mathrm{HO}$ cows during the first $4 \mathrm{yr}$ after first calving. Furthermore, $\mathrm{NO} \times$ $\mathrm{HO}, \mathrm{MO} \times \mathrm{HO}$, and $\mathrm{SR} \times \mathrm{HO}$ cows had significantly $(P<0.05)$ more revenue from production than did pure HO cows during the 4 yr after first calving. The greater lifetime production and revenue from production of the crossbreds was simply a consequence of their greater survival in these herds compared with pure HO cows.

On a percentage basis, the advantages for the crossbreds versus pure $\mathrm{HO}$ cows for fat plus protein production were $10.9 \%$ for $\mathrm{NO} \times \mathrm{HO}, 21.5 \%$ for $\mathrm{MO} \times \mathrm{HO}$, and $15.5 \%$ for $\mathrm{SR} \times \mathrm{HO}$ cows. The results for lifetime production are different from the study of McAllister et al. (1994), who reported that Ayrshire $\times$ HO cows had similar lifetime milk, fat, and protein production compared with pure HO cows. Heins et al. (2012) reported that Jersey $\times$ HO cows had similar lifetime milk, fat, and protein production compared with pure $\mathrm{HO}$ cows, but that study included only the first $1,220 \mathrm{~d}$ after first calving.

\section{Profitability}

For projected lifetime profit per cow (Table 6), NO $\times \mathrm{HO}(+\$ 1,120), \mathrm{MO} \times \mathrm{HO}(+\$ 2,156)$, and $\mathrm{SR} \times$ HO $(+\$ 1,925)$ cows all had significantly $(P<0.01)$ greater projected lifetime profit per cow than did pure HO cows. However, all of the crossbred groups had significantly $(P<0.01)$ more projected days of herd life than did pure HO cows (Table 6). Therefore, the greater lifetime profit was spread over many more days in the herd for the crossbreds compared with pure $\mathrm{HO}$ cows. Dairy producers typically have a fixed capacity for the number of cows in their herds - either the number of stalls in a barn or the amount of land for grazing.

Table 4. Survival to subsequent calving for Normande $\times$ Holstein, Montbéliarde $\times$ Holstein, and Scandinavian Red $\times$ Holstein crossbred cows compared with pure Holstein cows ${ }^{1}$

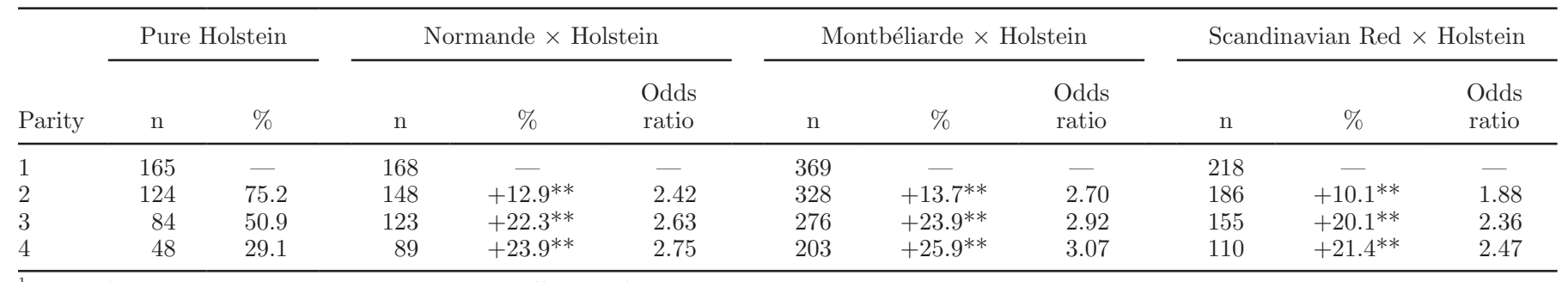

${ }^{1}$ Means for crossbred cows are expressed as a difference from pure Holsteins.

${ }^{* *} P<0.01$ for difference from pure Holsteins. 


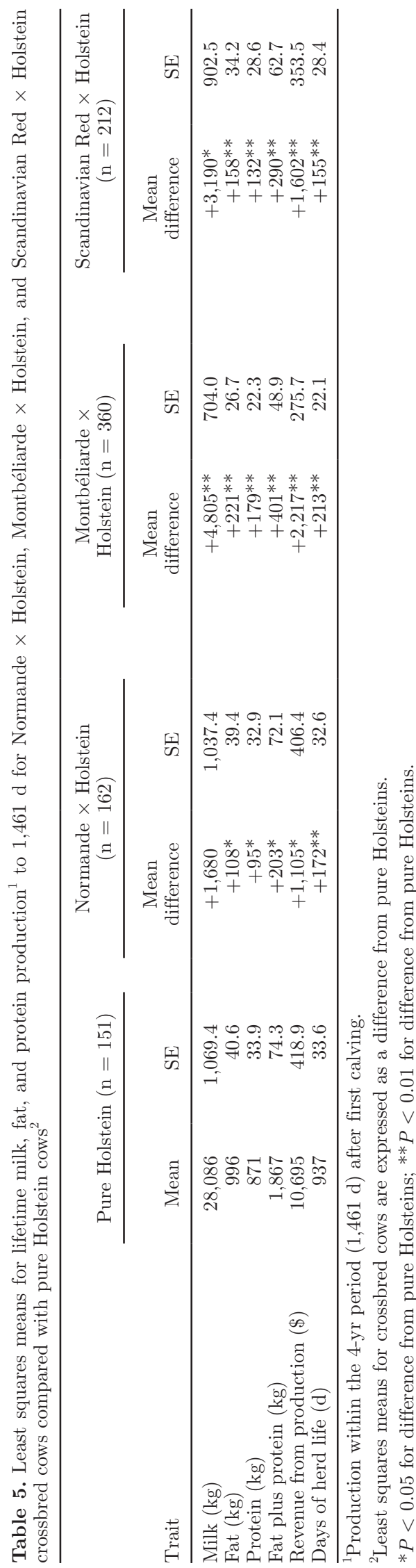

Consequently, the opportunity for profit per day from a fixed number of cows in the herd is likely of most economic importance for dairy producers.

The $\mathrm{NO} \times \mathrm{HO}$ cows had significantly $(P<0.01)$ less profit per day $(-\$ 0.28)$ than did pure HO cows; however, the $\mathrm{MO} \times \mathrm{HO}(+\$ 0.22)$ and $\mathrm{SR} \times \mathrm{HO}$ $(+\$ 0.15)$ cows had significantly $(P<0.01)$ more profit per day than pure HO cows. The differences among the crossbred breed groups for profit per day were rather striking, because the $\mathrm{MO} \times \mathrm{HO}$ crossbreds had $5.3 \%$ more profit per day and the $\mathrm{SR} \times \mathrm{HO}$ crossbreds had $3.6 \%$ more profit per day compared with the pure HO cows; however, the $\mathrm{NO} \times \mathrm{HO}$ crossbreds had $6.7 \%$ less profit per day than did the pure HO cows. The results suggest projected profit per cow-day of $\mathrm{NO} \times \mathrm{HO}$ cows was unfavorable at the high production levels of these confinement herds in California. Perhaps, $\mathrm{NO} \times \mathrm{HO}$ cows would perform better for daily profit compared with pure $\mathrm{HO}$ cows in low-input grazing environments.

The results for opportunity for profit per cow-day differed substantially from the results for lifetime profit per cow for the breed groups. The advantages for profit per day of the $\mathrm{MO} \times \mathrm{HO}$ and $\mathrm{SR} \times \mathrm{HO}$ crossbred cows over pure HO cows may seem modest. However, the daily profit margin must be multiplied by $365 \mathrm{~d}$ to estimate annual difference in profit, and the estimates of profit per day ignore potential differences in breed groups for health costs. The additional profit per day on an annual basis was $\$ 80$ for $\mathrm{MO} \times \mathrm{HO}$ and $\$ 55$ for $\mathrm{SR} \times \mathrm{HO}$ cows compared with pure HO cows, which, for a 250-cow herd, would result in an additional annual profit of $\$ 20,000$ for $\mathrm{MO} \times \mathrm{HO}$ cows and $\$ 13,750$ for $\mathrm{SR} \times \mathrm{HO}$ cows compared with pure $\mathrm{HO}$ cows.

The specific partitions of revenue and costs that contributed to projected lifetime profit per cow and projected profit per cow-day are in Tables 7 and 8 , respectively. All crossbred groups had significantly $(P$ $<0.01$ ) more lifetime revenue than did pure HO cows from production, from the SCC premium, and from the value of calves (Table 7). Specifically, the highest revenue was from the fat and protein solids in milk, especially the protein solids.

For lifetime costs, crossbred cows had significantly $(P$ $<0.05$ ) higher feed cost, breeding cost, fixed lactation cost, and fixed dry cow cost than did pure HO cows (Table 8). Not surprisingly, feed cost was the highest expense for all breed groups of cows, and all of the crossbred groups had significantly $(P<0.01)$ greater feed cost than did pure HO cows. The expense for each of these categories was logically higher, because the crossbred groups of cows remained in the herds 300 to $400 \mathrm{~d}$ longer than the pure HO cows (Table 6).

For profit per day (Table 8$), \mathrm{NO} \times \mathrm{HO}$ cows had significantly $(P<0.01)$ less value of milk on a daily 
Table 6. Least squares means for projected days of herd life, projected lifetime profit per cow, and projected profit per cow-day for Normande $\times$ Holstein, Montbéliarde $\times$ Holstein, and Scandinavian Red $\times$ Holstein crossbred cows compared with pure Holstein cows ${ }^{1}$

\begin{tabular}{|c|c|c|c|c|c|c|c|c|}
\hline \multirow[b]{2}{*}{ Item } & \multicolumn{2}{|c|}{$\begin{array}{l}\text { Pure Holstein } \\
\quad(\mathrm{n}=165)\end{array}$} & \multicolumn{2}{|c|}{$\begin{array}{c}\text { Normande } \times \text { Holstein } \\
(\mathrm{n}=168)\end{array}$} & \multicolumn{2}{|c|}{$\begin{array}{c}\text { Montbéliarde } \times \\
\text { Holstein }(\mathrm{n}=369)\end{array}$} & \multicolumn{2}{|c|}{$\begin{array}{c}\text { Scandinavian Red } \times \\
\text { Holstein }(\mathrm{n}=218)\end{array}$} \\
\hline & Mean & $\mathrm{SE}$ & $\begin{array}{l}\text { Mean } \\
\text { difference }\end{array}$ & $\mathrm{SE}$ & $\begin{array}{l}\text { Mean } \\
\text { difference }\end{array}$ & $\mathrm{SE}$ & $\begin{array}{l}\text { Mean } \\
\text { difference }\end{array}$ & $\mathrm{SE}$ \\
\hline Days of herd life & 946 & 50.0 & $+317^{* *}$ & 49.8 & $+412^{* *}$ & 33.9 & $+360^{* *}$ & 43.5 \\
\hline Lifetime profit (\$) & 4,347 & 309.1 & $+1,120^{* *}$ & 307.6 & $+2,156^{* *}$ & 209.8 & $+1,925^{* *}$ & 268.8 \\
\hline Profit per day (\$) & 4.17 & 0.01 & $-0.28^{* *}$ & 0.01 & $+0.22^{* *}$ & 0.01 & $+0.15^{* *}$ & 0.01 \\
\hline
\end{tabular}

${ }^{1}$ Means for crossbred cows are expressed as a difference from pure Holsteins.

$* * P<0.01$ for difference from pure Holsteins.

basis than did pure HO cows. On the other hand, the $\mathrm{NO} \times \mathrm{HO}$ cows had the lowest feed cost per day of all breed groups, which was significantly $(P<0.01)$ lower than that of pure HO cows. Replacement costs were the second largest expense for all breed groups on a daily basis after feed cost, and $\mathrm{NO} \times \mathrm{HO}(-\$ 0.38)$, $\mathrm{MO} \times \mathrm{HO}(-\$ 0.49)$, and SR $\times \mathrm{HO}(-\$ 0.41)$ cows had significantly $(P<0.01)$ lower replacement cost per day than did pure HO cows. The crossbreds survived longer and calved more frequently than the pure HO cows; therefore, they produced more female offspring.

Costs for health treatments were not available from the herds in this study, and inclusion of costs for health treatments may have affected the results for profit. For all livestock species, heterosis tends to be expressed most notably for traits related to fitness; therefore, the inability to compare the crossbred cows with pure HO cows for health costs is a glaring deficiency of this study. Increased health cost of pure HO cows over time is a major justification provided by dairy producers for deciding to use crossbreeding. Testimonials from the owners of these 3 herds indicated that crossbreds had fewer health problems near the time of calving and fewer metabolic disorders throughout their lifetimes. The results of this study were similar to those of VanRaden and Sanders (2003), who reported that crossbred cows had more profit than pure $\mathrm{HO}$ cows without the inclusion of health costs.

\section{Sensitivity Analysis}

Results from the sensitivity analysis for projected lifetime profit per cow are in Table 9. A higher feed cost decreased the difference between all of the crossbred groups and pure HO cows compared with default values; however, the crossbred groups continued to have a significant advantage for projected lifetime profit per cow (Table 9). Consequently, the $\mathrm{NO} \times \mathrm{HO}$ gained

Table 7. Least squares means for projected lifetime profit per cow by specific component of revenue and cost for Normande $\times$ Holstein, Montbéliarde $\times$ Holstein, and Scandinavian Red $\times$ Holstein crossbred cows compared with pure Holstein cows ${ }^{1}$

\begin{tabular}{|c|c|c|c|c|c|c|c|c|}
\hline \multirow[b]{2}{*}{ Item } & \multicolumn{2}{|c|}{$\begin{array}{l}\text { Pure Holstein } \\
\quad(\mathrm{n}=165)\end{array}$} & \multicolumn{2}{|c|}{$\begin{array}{c}\text { Normande } \times \text { Holstein } \\
(\mathrm{n}=168)\end{array}$} & \multicolumn{2}{|c|}{$\begin{array}{l}\text { Montbéliarde } \times \\
\text { Holstein }(\mathrm{n}=369)\end{array}$} & \multicolumn{2}{|c|}{$\begin{array}{c}\text { Scandinavian Red } \times \\
\text { Holstein }(\mathrm{n}=218)\end{array}$} \\
\hline & Mean & SE & $\begin{array}{c}\text { Mean } \\
\text { difference }\end{array}$ & $\mathrm{SE}$ & $\begin{array}{l}\text { Mean } \\
\text { difference }\end{array}$ & $\mathrm{SE}$ & $\begin{array}{l}\text { Mean } \\
\text { difference }\end{array}$ & $\mathrm{SE}$ \\
\hline \multicolumn{9}{|l|}{ Revenue (\$) } \\
\hline Milk volume & 638 & 35.1 & $+128^{* *}$ & 34.9 & $+239 * *$ & 34.9 & $+211^{* *}$ & 30.5 \\
\hline Fat solids & 3,178 & 184.3 & $+811^{* *}$ & 183.4 & $+1,368^{* *}$ & 125.1 & $+1,213^{* *}$ & 160.3 \\
\hline SCC premium & 141 & 9.3 & $+38^{* *}$ & 9.2 & $+68^{* *}$ & 6.3 & $+60 * *$ & 8.0 \\
\hline Calf value & 443 & 26.2 & $+148^{* *}$ & 26.0 & $+202^{* *}$ & 17.7 & $+149^{* *}$ & 22.7 \\
\hline Salvage value & 433 & 13.0 & +19 & 12.9 & +15 & 246.3 & +18 & 11.3 \\
\hline \multicolumn{9}{|l|}{ Cost $(\$)$} \\
\hline Dead cow disposal cost & 19 & 3.2 & -4 & 3.1 & -5 & 2.1 & -5 & 2.8 \\
\hline Feed cost & 4,552 & 245.2 & $+1,221^{* *}$ & 244.0 & $+1,842^{* *}$ & 166.4 & $+1,617^{* *}$ & 213.2 \\
\hline Replacement cost & 1,260 & 0.0 & 0 & 0.0 & 0 & 0.0 & 0 & 0.0 \\
\hline
\end{tabular}

${ }^{1}$ Means for crossbred cows are expressed as a difference from pure Holsteins.

${ }^{*} P<0.05$ for difference from pure Holsteins; ${ }^{* *} P<0.01$ for difference from pure Holsteins. 
Table 8. Least squares means for projected profit per cow-day by specific component of revenue and cost for Normande $\times$ Holstein, Montbéliarde $\times$ Holstein, and Scandinavian Red $\times$ Holstein crossbred cows compared with pure Holstein cows ${ }^{1}$

\begin{tabular}{|c|c|c|c|c|c|c|c|c|}
\hline \multirow[b]{2}{*}{ Item } & \multicolumn{2}{|c|}{$\begin{array}{l}\text { Pure Holstein } \\
\quad(\mathrm{n}=165)\end{array}$} & \multicolumn{2}{|c|}{$\begin{array}{c}\text { Normande } \times \text { Holstein } \\
(\mathrm{n}=168)\end{array}$} & \multicolumn{2}{|c|}{$\begin{array}{c}\text { Montbéliarde } \times \\
\text { Holstein }(\mathrm{n}=369)\end{array}$} & \multicolumn{2}{|c|}{$\begin{array}{c}\text { Scandinavian Red } \times \\
\text { Holstein }(\mathrm{n}=218)\end{array}$} \\
\hline & Mean & $\mathrm{SE}$ & $\begin{array}{c}\text { Mean } \\
\text { difference }\end{array}$ & $\mathrm{SE}$ & $\begin{array}{l}\text { Mean } \\
\text { difference }\end{array}$ & $\mathrm{SE}$ & $\begin{array}{c}\text { Mean } \\
\text { difference }\end{array}$ & $\mathrm{SE}$ \\
\hline \multicolumn{9}{|l|}{ Revenue (\$) } \\
\hline Milk volume & 0.68 & 0.000 & $-0.08^{* *}$ & 0.000 & $-0.04^{* *}$ & 0.000 & $-0.04^{* *}$ & 0.000 \\
\hline Fat solids & 3.37 & 0.001 & $-0.22^{* *}$ & 0.001 & $-0.01^{* *}$ & 0.001 & $-0.03^{* *}$ & 0.001 \\
\hline SCC premium & 0.15 & 0.000 & $-0.01 * *$ & 0.000 & $+0.01^{* *}$ & 0.000 & 0.00 & 0.000 \\
\hline Calf value & 0.48 & 0.001 & $-0.02^{* *}$ & 0.001 & 0.00 & 0.001 & $-0.02^{* *}$ & 0.001 \\
\hline Salvage value & 0.44 & 0.003 & $-0.07^{* *}$ & 0.002 & $-0.11^{* *}$ & 0.002 & $-0.09^{* *}$ & 0.002 \\
\hline \multicolumn{9}{|l|}{ Cost $(\$)$} \\
\hline Dead cow disposal cost & 0.03 & 0.001 & $-0.02 * *$ & 0.001 & $-0.02^{* *}$ & 0.000 & $-0.02^{* *}$ & 0.001 \\
\hline Feed cost & 4.82 & 0.001 & $-0.25^{* *}$ & 0.001 & $-0.12^{* *}$ & 0.000 & $-0.10^{* *}$ & 0.001 \\
\hline Replacement cost & 1.43 & 0.01 & $-0.38^{* *}$ & 0.01 & $-0.49^{* *}$ & 0.01 & $-0.41^{* *}$ & 0.01 \\
\hline
\end{tabular}

${ }^{1}$ Means for crossbred cows are expressed as a difference from pure Holsteins.

$* * P<0.01$ for difference from pure Holsteins.

$(-\$ 0.28$ to $-\$ 0.25)$ for profit per day relative to the pure HO cows. Furthermore, higher feed costs had a proportionately greater effect on $\mathrm{NO} \times \mathrm{HO}$ and pure $\mathrm{HO}$ cows $(-39 \%)$ than on the $\mathrm{MO} \times \mathrm{HO}$ and $\mathrm{SR} \times \mathrm{HO}$ cows $(-30 \%)$.

A higher milk price resulted in much higher $(P<$ 0.01) lifetime profit for the crossbred groups compared with pure HO cows, which was simply a reflection of their higher lifetime production. For profit per day, the difference of $\mathrm{NO} \times \mathrm{HO}$ and pure $\mathrm{HO}$ cows expanded from $-\$ 0.28$ to $-\$ 0.58$ with the higher milk price. The $\mathrm{MO} \times \mathrm{HO}(+\$ 0.08)$ cows continued to have significantly $(P<0.01)$ greater profit per day with the higher milk price than did pure $\mathrm{HO}$ cows, but the difference from pure $\mathrm{HO}$ cows was reduced.
A lower milk price dramatically reduced lifetime profit for all breed groups, but $\mathrm{NO} \times \mathrm{HO}$ cows were no longer significantly different from pure $\mathrm{HO}$ cows when milk price was lower. However, $\mathrm{MO} \times \mathrm{HO}$ and $\mathrm{SR} \times$ HO cows continued to have substantial $(P<0.01)$ advantages $(+101 \%$ and $+89 \%$, respectively) compared with pure $\mathrm{HO}$ cows for lifetime profit. The gap between $\mathrm{NO} \times \mathrm{HO}$ and pure $\mathrm{HO}$ cows was substantially reduced for profit per day $(-\$ 0.28$ to $-\$ 0.06)$ at the lower milk price; however, the $\mathrm{MO} \times \mathrm{HO}(+\$ 0.22$ to $+\$ 0.24)$ and $\mathrm{SR} \times \mathrm{HO}(+\$ 0.15$ to $+\$ 0.16)$ cows had greater advantage over pure HO cows when milk price was lower.

The higher replacement cost increased profit per day (Table 10) for $\mathrm{NO} \times \mathrm{HO}(-\$ 0.28$ to $-\$ 0.19)$, $\mathrm{MO} \times$ $\mathrm{HO}(\$ 0.22$ to $\$ 0.34)$, and $\mathrm{SR} \times \mathrm{HO}(\$ 0.15$ to $\$ 0.24)$

Table 9. Least squares means for projected lifetime profit per cow from sensitivity analysis for Normande $\times$ Holstein, Montbéliarde $\times$ Holstein, and Scandinavian Red $\times$ Holstein crossbred cows compared with pure Holstein cows ${ }^{1}$

\begin{tabular}{|c|c|c|c|c|c|c|c|c|}
\hline \multirow[b]{2}{*}{ Scenario } & \multicolumn{2}{|c|}{$\begin{array}{l}\text { Pure Holstein } \\
\quad(\mathrm{n}=165)\end{array}$} & \multicolumn{2}{|c|}{$\begin{array}{l}\text { Normande } \times \text { Holstein } \\
(\mathrm{n}=168)\end{array}$} & \multicolumn{2}{|c|}{$\begin{array}{c}\text { Montbéliarde } \times \\
\text { Holstein }(\mathrm{n}=369)\end{array}$} & \multicolumn{2}{|c|}{$\begin{array}{c}\text { Scandinavian Red } \times \\
\text { Holstein }(\mathrm{n}=218)\end{array}$} \\
\hline & Mean & $\mathrm{SE}$ & $\begin{array}{c}\text { Mean } \\
\text { difference }\end{array}$ & $\mathrm{SE}$ & $\begin{array}{c}\text { Mean } \\
\text { difference }\end{array}$ & SE & $\begin{array}{c}\text { Mean } \\
\text { difference }\end{array}$ & $\mathrm{SE}$ \\
\hline Default revenue and expenses $(\$)$ & 4,347 & & $+1,120$ & & $+2,156$ & & $+1,925$ & \\
\hline Higher feed cost $(\$ 0.3171 / \mathrm{kg})$ & 2,690 & 225.2 & $+682^{*}$ & 224.1 & $+1,497^{* *}$ & 152.8 & $+1,339^{* *}$ & 195.8 \\
\hline Higher milk price $(\$ 0.4544 / \mathrm{kg})$ & 7,849 & 507.0 & $+2,019^{* *}$ & 504.4 & $+3,626^{* *}$ & 344.1 & $+3,238^{* *}$ & 440.9 \\
\hline Higher salvage value $(\$ 800)$ & 4,553 & 312.4 & $+1,135^{* *}$ & 310.8 & $+2,175^{* *}$ & 212.0 & $+1,938^{* *}$ & 271.6 \\
\hline Heavier $\mathrm{BW}$ for $\mathrm{NO}$ and $\mathrm{MO}^{2}$ & 4,412 & 312.5 & $+1,057^{*}$ & 310.9 & $+2,100^{* *}$ & 212.1 & $+1,963^{* *}$ & 271.8 \\
\hline
\end{tabular}

${ }^{1}$ Means for crossbred cows are expressed as a difference from pure Holsteins.

${ }^{2} \mathrm{NO}=$ Normande $\times$ Holstein, $\mathrm{MO}=$ Montbéliarde $\times$ Holstein.

${ }^{*} P<0.05$ for difference from pure Holsteins; ${ }^{* *} P<0.01$ for difference from pure Holsteins. 
Table 10. Least squares means for projected profit per cow-day from sensitivity analysis for Normande $\times$ Holstein, Montbéliarde $\times$ Holstein, and Scandinavian Red $\times$ Holstein crossbred cows compared with pure Holstein cows ${ }^{1}$

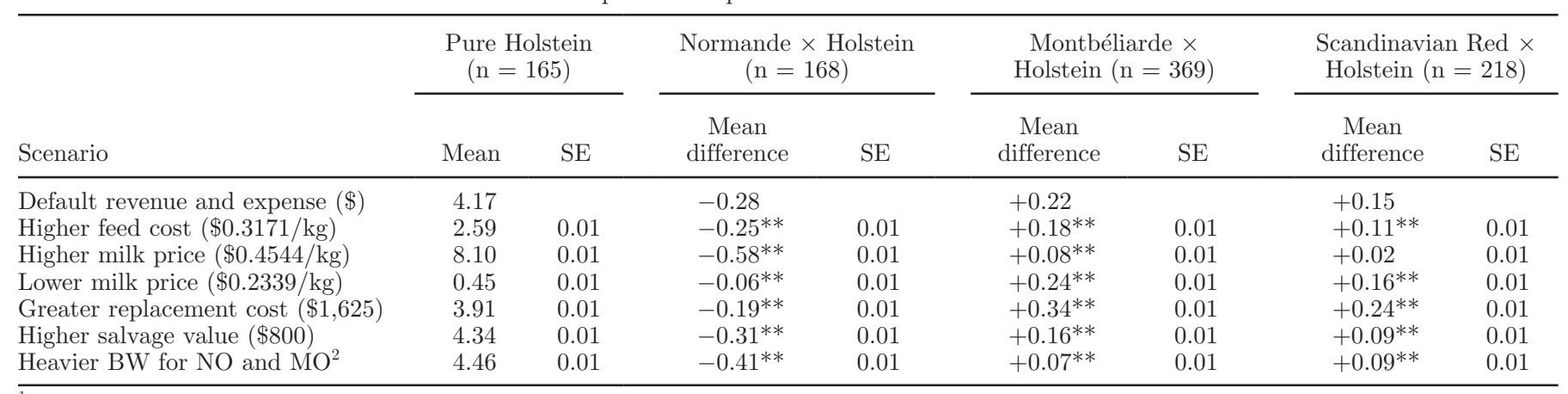

${ }^{1}$ Means for crossbred cows are expressed as a difference from pure Holsteins.

${ }^{2} \mathrm{NO}=$ Normande $\times$ Holstein, $\mathrm{MO}=$ Montbéliarde $\times$ Holstein.

${ }^{* *} P<0.01$ for difference from pure Holsteins.

cows compared with pure HO cows. Dairy producers are aware of the cost of raising a replacement heifer, and the results of this study indicate that more profit per day can be achieved from crossbreeding compared with pure HO when replacement costs are greater. The current study assumed the same cost $(\$ 1,200)$ to raise a crossbred or pure HO heifer. However, the difference for lifetime profit may have been greater for crossbreds than pure HO because crossbred young stock may have higher survival and enhanced fertility and, therefore, fewer days to first calving, which results in reduced rearing costs of heifers.

The higher salvage value did not affect the results for difference in lifetime profit per cow of crossbred versus pure HO cows; however, for profit per cow-day, the difference from pure $\mathrm{HO}$ increased $\$ 0.03$ for $\mathrm{NO} \times$ $\mathrm{HO}$ cows, and decreased $\$ 0.06$ for $\mathrm{MO} \times \mathrm{HO}$ and $\mathrm{SR}$ $\times \mathrm{HO}$ cows. Fewer crossbred versus pure $\mathrm{HO}$ cows were culled on a given day in the herd, which resulted in less revenue from salvage value on a daily basis for the crossbreds. Also, the difference between replacement cost and salvage value has a large effect on the profitability of dairying. When salvage value is very high and replacement cost is very low, the cost of replacing cows becomes quite small. On the other hand, when salvage value is low and replacement cost is high, replacing cows is very costly.

Results for profit per day with increased $\mathrm{BW}$ of $\mathrm{NO}$ $\times \mathrm{HO}$ and $\mathrm{MO} \times \mathrm{HO}$ cows must be interpreted with caution. As expected, the profit per day was reduced for the $\mathrm{NO} \times \mathrm{HO}(-\$ 0.13)$ and $\mathrm{MO} \times \mathrm{HO}(-\$ 0.15)$ crossbred cows with the higher BW. Some may assume $\mathrm{NO} \times \mathrm{HO}$ and $\mathrm{MO} \times \mathrm{HO}$ crossbred cows consume more $\mathrm{DM}$ than do pure $\mathrm{HO}$ cows because of greater $\mathrm{BW}$; however, the potential for greater $\mathrm{BW}$ of $\mathrm{NO} \times \mathrm{HO}$ and $\mathrm{MO} \times \mathrm{HO}$ cows may not actually reflect increased DMI compared with pure HO cows. First, the greater BW of
$\mathrm{MO} \times \mathrm{HO}$ crossbreds is expected to result from greater body condition and not from greater frame size (Hazel et al., 2009) and second, heterosis is anticipated for feed efficiency of dairy cattle. Hazel et al. (2009) reported that $\mathrm{MO} \times \mathrm{HO}$ cows were similar to pure $\mathrm{HO}$ cows for DMI (numerically, the crossbreds were $1 \mathrm{~kg} / \mathrm{d}$ lower for DMI) and identical for fat plus protein production; however, the $\mathrm{MO} \times \mathrm{HO}$ cows had more body condition with no difference in hip height.

Unfortunately, health costs are often overlooked by dairy producers when assessing the profitability of alternative genotypes of dairy cattle. For this study, lifetime profit per cow and profit per cow-day excluded health costs, because health events were not provided by the herd owners. Data on health costs will be important for dairy producers to compare crossbred and pure HO cows. Moreover, dairy producers typically prefer to work with cows with fewer health problems. Therefore, additional research that includes routine collection of health costs is needed to fully assess the profitability of $\mathrm{NO} \times \mathrm{HO}, \mathrm{MO} \times \mathrm{HO}$, and $\mathrm{SR} \times \mathrm{HO}$ cows compared with pure $\mathrm{HO}$ cows.

Research has been initiated around the world to compare $\mathrm{NO} \times \mathrm{HO}, \mathrm{MO} \times \mathrm{HO}$, and $\mathrm{SR} \times \mathrm{HO}$ crossbred cows to pure HO cows for profitability, and some of these studies include health costs. Regardless of breeds used for crossbreeding, complete recording of production, survival, fertility, and health is essential to assess the profitability of crossbred versus purebred cows.

\section{CONCLUSIONS}

Dairy producers may improve the survival of cows and the profitability of dairying by crossing pure $\mathrm{HO}$ cows with bulls of at least some other breeds of dairy cattle. The $\mathrm{NO} \times \mathrm{HO}, \mathrm{MO} \times \mathrm{HO}$, and $\mathrm{SR} \times \mathrm{HO}$ cows had more projected lifetime profit per cow than did 
pure HO cows; however, crossbreds remained in herds much longer to achieve the substantial advantages for projected lifetime profit per cow. Projected profit per cow-day was significantly greater for $\mathrm{MO} \times \mathrm{HO}$ $(+\$ 0.22)$ and $\mathrm{SR} \times \mathrm{HO}(+\$ 0.15)$ than for pure $\mathrm{HO}$ cows, but significantly lower for $\mathrm{NO} \times \mathrm{HO}(-\$ 0.28)$ than pure $\mathrm{HO}$ cows in these confinement dairies.

\section{ACKNOWLEDGMENTS}

The authors are especially grateful to the managers of the 6 California herds, who willingly provided data from their cows. Without their cooperation, this study would not have been possible.

\section{REFERENCES}

Bailey, K. W., C. M. Jones, and A. J. Heinrichs. 2005. Economic returns to Holstein and Jersey herds under multiple component pricing. J. Dairy Sci. 88:2269-2280.

Brealey, R. A., S. C. Myers, and A. J. Marcus. 2009. Fundamentals of Corporate Finance. McGraw Hill, New York, NY.

California Department of Food and Agriculture. 2009. California Cost of Production 2009 Annual. Dairy Marketing Branch, Sacramento, CA.

Cole, J. B., D. J. Null, and P. M. VanRaden. 2009. Best prediction of yields for long lactations. J. Dairy Sci. 92:1796-1810.

Cole, J. B. and P. M. VanRaden. 2010. Net merit as a measure of lifetime profit: 2010 revision. Accessed July 2010. http://aipl.arsusda.gov/reference/nmcalc.htm. Animal Improvement Programs Laboratory, ARS-USDA, Beltsville, MD.

Dechow, C. D., and R. C. Goodling. 2008. Mortality, live culling by sixty days in milk, and production profiles in high- and low-survival Pennsylvania herds. J. Dairy Sci. 91:4630-4639.

Gunjal, K., L. Menard, and R. Shanmugam. 1997. Economic analysis of crossbreeding dairy cattle. Agric. Syst. 54:327-339.

Hare, E., H. D. Norman, and J. R. Wright. 2006. Survival rates and productive herd life of dairy cattle in the United States. J. Dairy Sci. 89:3713-3720.

Hazel, A. R., B. J. Heins, L. B. Hansen, A. J. Seykora, D. G. Johnson, and J. G. Linn. 2009. Montbeliarde-sired crossbred cows compared to pure Holstein cows for body weight, body condition score, hip height, dry matter intake, and production during the first 150 days of first lactation. J. Dairy Sci. 92(E-Suppl. 1):568. (Abstr.)

Heins, B. J., and L. B. Hansen. 2012. Short communication: Fertility, somatic cell score, and production of Normande $\times$ Holstein, Montbéliarde $\times$ Holstein, and Scandinavian Red $\times$ Holstein crossbreds versus pure Holsteins during their first 5 lactations. J. Dairy Sci. 95:918-924. doi:10.3168/jds.2011-4523.

Heins, B. J., L. B. Hansen, and A. J. Seykora. 2006a. Fertility and survival of pure Holsteins versus crossbreds of Holstein with Normande, Montbeliarde, and Scandinavian Red. J. Dairy Sci. 89:4944-4951.
Heins, B. J., L. B. Hansen, and A. J. Seykora. 2006b. Production of pure Holsteins versus crossbreds of Holstein with Normande, Montbeliarde, and Scandinavian Red. J. Dairy Sci. 89:2799-2804.

Heins, B. J., L. B. Hansen, A. J. Seykora, A. R. Hazel, D. G. Johnson, and J. G. Linn. 2011. Short communication: Crossbreds of Jersey $\times$ Holstein compared with pure Holsteins for production, mastitis, and body measurements during the first three lactations. J. Dairy Sci. 94:501-506.

Hocking, P. M., A. J. McAllister, M. S. Wolynetz, T. R. Batra, A. J. Lee, C. Y. Lin, G. L. Roy, J. A. Vesely, J. M. Wauthy, and K. A. Winter. 1988. Factors affecting length of herdlife in purebred and crossbred dairy cattle. J. Dairy Sci. 71:1011-1024.

McAllister, A. J., A. J. Lee, T. R. Batra, C. Y. Lin, G. L. Roy, J. A. Vesely, J. M. Wauthy, and K. A. Winter. 1994. The influence of additive and nonadditive gene action on lifetime yields and profitability of dairy cattle. J. Dairy Sci. 77:2400-2414.

McDowell, R. E., and B. T. McDaniel. 1968. Interbreed matings in dairy cattle. I. Yield traits, feed efficiency, type and rate of milking. J. Dairy Sci. 51:767-777.

Meadows, C., P. J. Rajala-Schultz, and G. S. Frazer. 2005. A spreadsheet-based model demonstrating the nonuniform economic effects of varying reproductive performance in Ohio dairy herds. J. Dairy Sci. 88:1244-1254

Miller, R. H., M. T. Kuhn, H. D. Norman, and J. R. Wright. 2008. Death losses for lactation cows in herds enrolled in Dairy Herd Improvement test plans. J. Dairy Sci. 91:3710-3715.

Norman, H. D., J. R. Wright, S. M. Hubbard, R. H. Miller, and J. L. Hutchison. 2009. Reproductive status of Holstein and Jersey cows in the United States. J. Dairy Sci. 92:3517-3528.

NRC. 2001. Nutrient Requirements of Dairy Cattle. 7th rev. ed. Natl. Acad. Sci., Washington, DC.

Pinedo, P. J., A. De Vries, and D. W. Webb. 2010. Dynamics of culling risk with disposal codes reported by Dairy Herd Improvement herds. J. Dairy Sci. 93:2250-2261.

SAS Institute. 2008. SAS/STAT Software. Release 9.2. SAS Inst. Inc. Cary, NC

Sørensen, M. K., E. Norberg, J. Peterson, and L. G. Christensen. 2008. Invited review: Crossbreeding in dairy cattle: A Danish perspective. J. Dairy Sci. 91:4116-4128.

Touchberry, R. W. 1992. Crossbreeding effects in dairy cattle: The Illinois experiment, 1949 to 1969. J. Dairy Sci. 75:640-667.

USDA-AMS (Agricultural Marketing Service). 2010. Milk Marketing Order Statistics Public Database. Accessed Jan. 16, 2010. http:// apps.ams.usda.gov/USDAMIB/Main/Welcome.aspx.

VanRaden, P. M. 2006. Net merit as a measure of lifetime profit: 2006 revision. Animal Improvement Programs Laboratory, ARSUSDA, Beltsville, MD. Accessed December 2009. http://aipl.arsusda.gov/ reference/nmcalc.htm.

VanRaden, P. M., and A. H. Sanders. 2003. Economic merit of crossbred and purebred US dairy cattle. J. Dairy Sci. 86:1036-1044.

Vesely, J. A., A. J. McAllister, A. J. Lee, T. R. Batra, C. Y. Lin, G. L. Roy, J. M. Wauthy, and K. A. Winter. 1986. Reproductive performance of crossbred and purebred dairy cows. J. Dairy Sci. 69:518-526.

Weigel, K. A., R. W. Palmer, and D. Z. Caraviello. 2003. Investigation of factors affecting voluntary and involuntary culling in expanding dairy herds in Wisconsin using survival analysis. J. Dairy Sci. $86: 1482-1486$. 